\title{
Cognitive model for assessing the impact of personnel risks and conflicts in sci- entific projects
}

\author{
D. Bedrii ${ }^{1 *}$ I. Semko ${ }^{2 *}$ \\ ${ }^{1}$ State Enterprise “Ukrainian Scientific Research Institute of Radio and Television”, Odesa, Ukraine \\ ${ }^{2}$ Cherkasy State Technological University, Cherkasy, Ukraine \\ *Corresponding author. E-mail: ${ }^{1}$ dimi7928@gmail.com, ${ }^{2}$ semkoinga77@gmail.com
}

Paper received 07.08.19; Accepted for publication 20.08.19.

\section{https://doi.org/10.31174/SEND-NT2019-206VII25-08}

\begin{abstract}
Absract. This study contains materials on the application of project management methodology in any field of human activity, including scientific one. According to the analysis of publications of scientists, it has been established that cognitive modeling today is an effective tool for impact assessment of any factors on project implementation. It is suggested to assess the impact of personnel risks and conflicts that may arise in the process of implementing the scientific projects and have both positive and negative effects on them, using, the cognitive map and model are presented. It is established that the results of this modeling will give the head and members of his team a visual overview of the existing impact of personnel risks and conflicts.
\end{abstract}

Keywords: project management methodology, scientific project, cognitive modeling, impact assessment, personnel risks, conflicts.

Introduction. The project management methodology has been successfully implemented in the world and Ukraine and has proven to be an effective and efficient tool [1]. One of the main ways to improve any field of activity is to use the experience of previous projects. The use of cognitive models for the management of any project, including scientific ones, for project analyzing, formating, accumulating and updating of the knowledge base will provide the organization with effective tools in the future [2]. Scientific projects are time consuming [3], so there is a need for further study on the impact of personnel risks and conflicts on the scientific project implementation.

Review of publications on the topic. The standard approaches, which are defined in project management standards, provide only the acquisition of lessons or the fixation of facts, parameters and quantities for which the project was unsuccessful [2]. To determine not only the facts, but also the causes of their occurrence is very important for success in the future. To do this, one can use a methodological approach such as cognitive modeling, which is one of the classes of simulation modeling, which is based on the construction and study of a cognitive situation map.

The problems of applying the cognitive approach in the organization management, organizational knowledge management, structuring of explicit and implicit knowledge are studied by authors in the article [4]. The study can be the basis for the formation of information flows of knowledge within any institution, including scientific one, and outside it.

The author of [5] analyzes the new direction of management - cognitive management, which emerged as one of the manifestations of cognitive economics. Also, the author suggested the possibility of using cognitive tools in the development of a personnel management system aimed at supporting the organization's strategy. The results of this study provide an effective tool for managing the project team.

Voitenko O.S. in the article [6] proposed to use the cognitive modeling in the framework of the targetoriented approach, that allowed increasing management efficiency, creating conditions for the establishment of market relations, implementing strategies for corporate development of the region. The results of this study can be the basis for their application in the process of planning projects, including scientific ones.

The algorithm of using dynamic cognitive modeling of active systems for planning and crisis management of housing and communal services reform in Ukraine is considered by Koshkin K. V., Makieiev S. A., Fomenko H. V. in the work [7]. The proposed mathematical apparatus of cognitive modeling can become the basis for optimization in the process of reforming any sphere of management activity.

Danchenko O. B. [8] suggested using cognitive modeling to determine the impact of project risks on themselves. This study showed that cognitive modeling will become an effective tool for determining the impact not only of risks, but also of conflicts in scientific projects.

The author of the article [9] considers cognitive models of human behavior from the point of view of conflict situations and communication problems and suggests the process of organization for reflective-cognitive communication in conflict solution processes. From this study, one can conclude that cognitive modeling can be applied in the process of assessing the impact of conflicts in scientific projects.

Based on the results of the analysis of publications, it can be concluded that human relations in any field of activity, including scientific one, require a more detailed analysis of their impact in order to eliminate and prevent risks and conflicts.

The aim of this study is to assess the impact of personnel risks and conflicts in scientific projects using cognitive modeling.

Materials and methods. The current project management methodology [1] offers a high-quality project risk management tool, which is being defined as a set of measures, including identification, qualitative and quantitative risk analysis, development and implementation of strategies aimed at reducing the probability and degree of their impact on the progress, results and products of these projects. As part of the risk analysis, a detailed qualitative and quantitative assessment is carried out to determine the degree of risk and make decision on the development of adequate response measures.

Using this tool, the personnel risks of a scientific project were identified, the results of which are presented in the form of Table. 1 [10]. 
Table 1. General characteristics of personnel risks of scientific project

\begin{tabular}{|c|l|l|}
\hline$№$ ח/ח & \multicolumn{1}{|c|}{ Name of the personnel risk group } & \multicolumn{1}{c|}{ Causes of personnel risk groups } \\
\hline 1 & Personnel Policy Risks ( $\left.\mathrm{R}_{1}\right)$ & $\begin{array}{l}\text { Errors in the development of personnel management directions, insufficient sub- } \\
\text { stantiation of project priorities, false setting of the project aim and inaccurate } \\
\text { presentation of specific tasks of the project personnel }\end{array}$ \\
\hline 2 & $\begin{array}{l}\text { Risks associated with personnel issues } \\
\left(\mathrm{R}_{2}\right)\end{array}$ & $\begin{array}{l}\text { Errors in recruitment, project documentation development, project timing and } \\
\text { budgeting, lack of staff qualifications, overload, fatigue and illness }\end{array}$ \\
\hline 3 & $\begin{array}{l}\text { Risks associated with an inefficient sys- } \\
\left.\text { tem of motivation and incentivation ( } \mathrm{R}_{3}\right)\end{array}$ & $\begin{array}{l}\text { Poor working conditions, unfulfilled needs and goals, lack of attention to ad- } \\
\text { vanced training, lack of financial and non-financial incentives, compensation } \\
\text { payments }\end{array}$ \\
\hline 4 & $\begin{array}{l}\text { Risks associated with confidentiality of } \\
\text { information in the project }\left(\mathrm{R}_{4}\right)\end{array}$ & Illegal collection, disclosure or use of confidential project information \\
\hline
\end{tabular}

In work [11], the authors proposed such a tool as conflict management of the scientific project, which includes processes related to the implementation of conflict management planning, identification, analysis, response planning, response, as well as monitoring conflicts in the project. The goal of conflict management of a scientific project is to maximize the probability of its (project) success- ful completion by increasing the probability of positive conflicts and enhancing their impact; reducing the probability of negative conflicts and reducing their impact. Based on this, the main types of conflicts were identified in the planning and implementation of scientific projects, which are given in the form of Table. 2 [12].

Table 2. Main types of project conflicts

\begin{tabular}{|c|c|c|}
\hline № s/n & Conflict types & Essence of the conflict \\
\hline 1 & 2 & 3 \\
\hline 1 & Relationship conflicts $\left(\mathrm{K}_{1}\right)$ & $\begin{array}{l}\text { If those who make decisions have personal relations with those whom these decisions con- } \\
\text { cern (family members, relatives, friends), to ensure the objectivity and limit the influence } \\
\text { of personal relationships (interests, both positive and negative), it is necessary to avoid } \\
\text { participation in making of these decisions. The main reason for these conflicts in scientific } \\
\text { teams is the succession of positions, in particular leading ones }\end{array}$ \\
\hline 2 & $\begin{array}{l}\text { Conflicts due to the occupa- } \\
\text { tion of several positions } \\
\text { (roles) in the scientific team } \\
\left(\mathrm{K}_{2}\right)\end{array}$ & $\begin{array}{l}\text { Such conflicts of official interests (real, potential, and imaginary) can be solved by avoid- } \\
\text { ing a decision that could interfere with balanced, objective judgment and conclusions, for } \\
\text { example, drawing collegial attention to possible prejudice and bias }\end{array}$ \\
\hline 3 & $\begin{array}{l}\text { Conflicts that arise due to the } \\
\text { use of resources of a scientific } \\
\text { institution }\left(\mathrm{K}_{3}\right)\end{array}$ & $\begin{array}{l}\text { In the case when the goals and objectives of a scientific project and an individual member } \\
\text { of its team coincide (for example, a scientific publication, an analytical note, etc.), the pro- } \\
\text { ject resources can be used. In other cases, this may cause conflict in the scientific project } \\
\text { team. }\end{array}$ \\
\hline 4 & $\begin{array}{l}\text { Conflicts that arise due to the } \\
\text { material and financial inter- } \\
\text { ests (K4) }\end{array}$ & $\begin{array}{l}\text { Members of the scientific project team, using intellectual property rights, have the right to } \\
\text { enter into transactions and freely sell their works created in the framework of their scien- } \\
\text { tific activity, without causing conflicts of interest, if this does not interfere with the fulfill- } \\
\text { ment of basic obligations }\end{array}$ \\
\hline 5 & $\begin{array}{l}\text { Conflicts that arise due to the } \\
\text { involvement in activity out- } \\
\text { side the main scientific organ- } \\
\text { ization }\left(\mathrm{K}_{5}\right)\end{array}$ & $\begin{array}{l}\text { Recently, research teams and their individual researchers have been increasingly cooperat- } \\
\text { ing and doing business with various government institutions and the private sector, with } \\
\text { public and private scientific foundations, both Ukrainian and foreign ones, which support } \\
\text { their study and use their knowledge and experience.Such cooperation is socially and eco- } \\
\text { nomically beneficial and profitable. }\end{array}$ \\
\hline 6 & $\begin{array}{l}\text { Conflicts of obligations that } \\
\text { arise regarding the ratio of } \\
\text { time spent, responsibilities } \\
\text { and obligations in a scientific } \\
\text { organization }\left(\mathrm{K}_{6}\right)\end{array}$ & $\begin{array}{l}\text { This type of conflict can arise when activities outside a scientific organization intersect } \\
\text { with activities in it and impede the fulfillment of obligations at primary place of employ- } \\
\text { ment.The main problem of these conflicts is the deterioration of the moral and psychologi- } \\
\text { cal state of the researcher, in particular, they can lead to fatigue, a state of constant stress, } \\
\text { and a performance decrement. }\end{array}$ \\
\hline
\end{tabular}

In addition to identifying personnel risks and conflicts in a scientific project, it is also necessary to assess their impact on themselves and each other, and cognitive modeling can be used to do this. This method has been used for a long time in project management in the process of project planning to study the relationship between the elements of economic systems in the decision-making of management decisions..

The use of cognitive models at the stage of analyzing personnel risks and conflicts contributes to a better understanding of problem situations, identifying contradictions and correct analyzing the risk and conflict system. In order to understand and analyze the structure of the relationship between personnel risks and conflicts of a scientific project, it is possible to construct a structural diagram of a causal relationship between personnel risks and conflicts.

Results and discussion. The process of cognitive modeling in the management of risks and conflicts in a scientific project will be based on their identification, that is, the pre-formed lists of personnel risks and conflicts, the relationship of which need to be studied. It is worth noting that attention should be paid to all personnel risks and conflicts of the project, regardless of the probability of their occurrence and degree of impact.

Next, It should been identified all the relationship between risks and conflicts that are considered. The risks and conflicts themselves, in this case, will act as vertices (factors) when constructing the cognitive map, and the relationships - as arcs. The results of cognitive modeling 
for impact assessment of such factors as personnel risks and conflicts are represented in the form of Table. 3.

Table 3. Cognitive map of the impact assessment of personnel risks and conflicts in scientific projects

\begin{tabular}{|c|c|c|c|c|c|c|c|c|c|c|}
\hline Factors & $\mathrm{R}_{1}$ & $\mathrm{R}_{2}$ & $\mathrm{R}_{3}$ & $\mathrm{R}_{4}$ & $\mathrm{~K}_{1}$ & $\mathrm{~K}_{2}$ & $\mathrm{~K}_{3}$ & $\mathrm{~K}_{4}$ & $\mathrm{~K}_{5}$ & $\mathrm{~K}_{6}$ \\
\hline $\mathrm{R}_{1}$ & 0 & -1 & 1 & 0 & 1 & -1 & 0 & 0 & 1 & -1 \\
\hline $\mathrm{R}_{2}$ & 1 & 0 & 0 & -1 & 0 & 1 & 0 & 1 & -1 & -1 \\
\hline $\mathrm{R}_{3}$ & 1 & -1 & 0 & 1 & -1 & 1 & 1 & 1 & -1 & 0 \\
\hline $\mathrm{R}_{4}$ & 1 & 1 & 1 & 0 & 0 & -1 & 0 & -1 & -1 & 0 \\
\hline $\mathrm{K}_{1}$ & 1 & -1 & 1 & 1 & 0 & -1 & -1 & -1 & 1 & 0 \\
\hline $\mathrm{K}_{2}$ & 1 & 1 & 0 & 0 & 1 & 0 & 1 & -1 & -1 & 1 \\
\hline $\mathrm{K}_{3}$ & 0 & 0 & 1 & 0 & 0 & 1 & 0 & 1 & -1 & 1 \\
\hline $\mathrm{K}_{4}$ & -1 & -1 & 1 & 0 & 1 & 1 & 1 & 0 & -1 & 1 \\
\hline $\mathrm{K}_{5}$ & -1 & 0 & 1 & -1 & -1 & -1 & 0 & 1 & 0 & -1 \\
\hline $\mathrm{K}_{6}$ & -1 & -1 & 0 & 0 & -1 & 0 & 0 & 1 & 0 & 0 \\
\hline
\end{tabular}

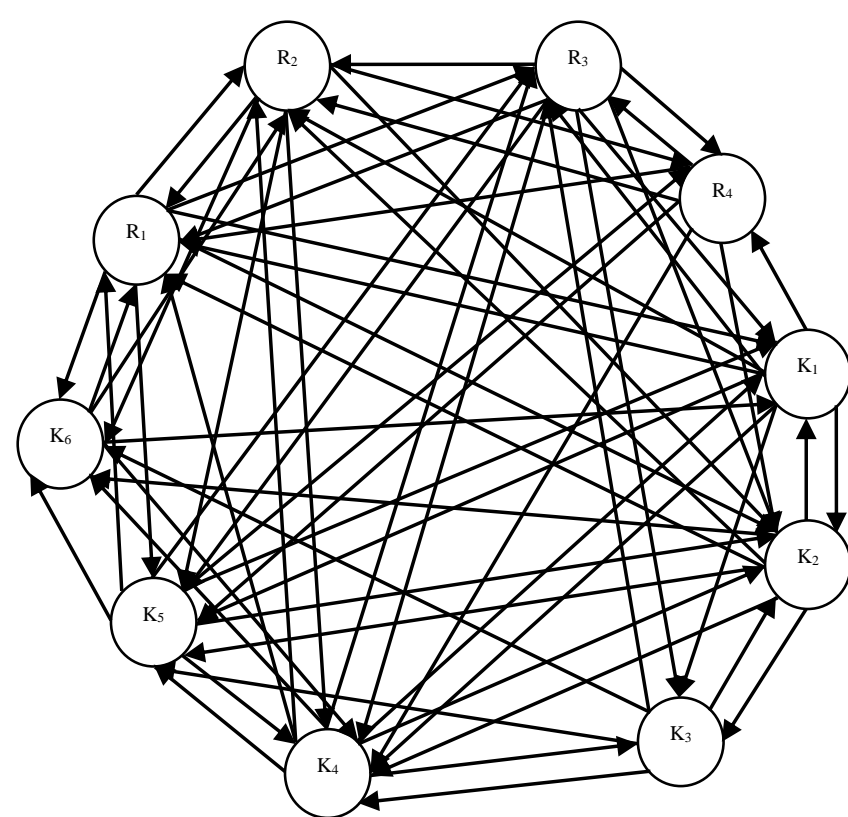

Fig. 1. Cognitive model of the impact of personnel risks and conflicts in scientific projects

Based on the data given in Table. 3, it can be concluded that the factors $\mathrm{R}_{3}, \mathrm{~K}_{1}$ and $\mathrm{K}_{4}$ have an impact on most of the project risks, and $\mathrm{R}_{1}, \mathrm{~K}_{2}, \mathrm{~K}_{4}$ and $\mathrm{K}_{5}$ are most sus- ceptible to such an impact. The table data serve as the basis for constructing a cognitive model of the impact of personnel risks and conflicts in scientific projects, which is represented in Fig. 1 and is the oriented graph reflecting the fact that there is a relationship between the factors.

The constructed model can be applied not only at the stage of identifying personnel risks and conflicts of a scientific project. It will also be advisable to use it in the process of analyzing them and developing a set of measures for managing personnel risks and conflicts of the scientific project. By expanding the model by including the corresponding additional impact factors, the effectiveness of certain planned measures can be studied.

Conclusions. The application of cognitive modeling in the planning and implementation of scientific projects, in particular for the management of personnel risks and conflict were suggested by the authors. Further research is aimed at optimizing the impact of personnel risks and conflicts using cognitive modeling, which provides the head of a scientific project and his team with a convenient tool for monitoring and controlling personnel risks and conflicts, which, in turn, will allow to complete a scientific project within the framework of the approved budget and a certain time.

\section{ЛITЕРАТУРА}

1. A Guide to the Project Management Body of Knowledge (PMBOK® Guide). Six Edition. USA. PMI, 2017. 574 p.

2. Бушуев С.Д. Креативные технологии в управлении проектами и программами: монография / С.Д. Бушуев, Н.С. Бушуева, И.А. Бабаев и др. К. : Саммит книга, 2010. 768 c.

3. Бедрій Д.І. Особливості проектно-орієнтованого управління науковими проектами / Д.I. Бедрій // Project, Program, Portfolio Management: матеріали Другої Міжнародної науково-практичної конференції 08-09 грудня 2017 року. Т. 2. Одеса : ОНПУ, 2017. С. 15-18.

4. Лазоренко Т.В. Когнітивний менеджмент як інноваційна стратегія управління організацією / Т.В. Лазоренко, М.П. Лазоренко // Ефективна економіка: Ел. фах. вид. www.economy.nauka.com.ua. № 4, 2018.

5. Кудрявцева Е.И. Когнитивная экономика и когнитивный менеджмент: новая концепция управления человеческими ресурсами / Кудрявцева Е.И. // Управленческое консультирование. 2014. № 4(64). С. 62-69.

6. Войтенко О.С. Когнітивні моделі управління проектами в програмно-цільовому управлінні / О.С. Войтенко // Містобудування та територіальне планування: наук.-техн. зб. Київ: КНУБА, 2010. № 38. С. 84-89.
7. Кошкин К.В. Когнитивные модели управления жилищнокоммунальным хозяйством как активной системой / К.В. Кошкин, С.А. Макеев, Г.В. Фоменко // Управління розвитком складних систем. К. : КНУБА, 2011. № 5. С. 17 19.

8. Данченко Е.Б. Когнитивное моделирование рисков проекта / Е.Б. Данченко // Тези доповідей $\mathrm{X}$ міжнародної конференції «Управління проектами у розвитку суспільства». Тема: Управління програмами та проектами в умовах глобальної фінансової кризи // Відпов. за вип. С.Д. Бушуев. К.: КНУБА, 2013. С. 64-66.

9. Дідковський С.В. Організація рефлексивно-когнітивного спілкування в процесах вирішення конфліктів / С.В. Дідковський // Актуальні проблеми психології: психологічна теорія і технологія навчання / за ред. С.Д. Максименко, М.Л. Смульсон. К.: вид-во НПУ ім. М.П. Драгоманова, 2010. Т. 8. Вип. 7. С. 52-62.

10. Данченко О.Б. Ідентифікація кадрових ризиків наукових проектів / О.Б. Данченко, Д.І. Бедрій, І.Б. Семко // Управління проектами та розвиток виробництва: Зб. наук.пр. Луганськ: вид-во СНУ ім. В.Даля, 2017. №4(64). C. $18-24$.

11. Данченко О.Б. Управління конфліктами наукових 
проектів / О.Б. Данченко, Д.І. Бедрій, І.Б. Семко // Вісник НТУ «ХПІ». Вісник НТУ «ХПІ». Серія: Стратегічне управління, управління портфелями, програмами та проектами. Х. : НТУ «ХПІ», 2019. № 2(1327). С. 28-35. DOI: $10.20998 / 2413-3000.2019 .1327 .5$.
12. Бедрій Д.І. Ідентифікація конфліктів у наукових проектах / Д.І. Бедрій // Project, Program, Portfolio Management. Матеріали Третьої Міжнародної науково-практичної конференції 07-08 грудня 2018 року. Т. 2. Одеса, ОНПУ, 2018. C. $17-20$.

\section{REFERENCES}

2. Bushuyev S. D., Bushuyeva N. S., Babayev I. A. et al. Kreativnye teknnologii $v$ upravlenii proyektami $i$ programmami: monografiya [Creative technologies in project and program management:monograph]. Kyiv, Samit-Kniga Publ., 2010. $768 \mathrm{p}$.

3. Bedrii D. I. Osoblyvosti proektno-oriientovanoho upravlinnia naukovymy proektamy [Special features of project-oriented management of scientific projects]. Materialy II Mizhnarodnoi naukovo praktychnoi konferentsii "Project, Program, Portfolio Management" [Proceedings of the $2^{\text {nd }}$ International Scientific and Practical Conference "Project, Program, Portfolio Management"]. Odesa, 2017, pp. 15-18.

4. Lazorenko T. V., Lazorenko M. P. Kohnityvnyi menedzhment yak innovatsiina stratehiia upravlinnia orhanizatsiieiu [Cognitive management as an innovative strategy of management of the organization]. Efektyvna ekonomika [Effective economics], 2018, no. 4 . Available at: www.economy.nauka.com.ua

5. Kudryavtseva Ye. I. Kognitivnaya ekonomika i kognitivnyy menedzhment: novaya kontseptsiya upravleniya chelovecheskimi resursami [Cognitive economics and cognitive management: a new concept of human resource management]. Upravlencheskoye konsultirovaniye [Management consulting], 2014, no. 4 (64), pp. 62-69.

6. Voytenko O. S. Kohnityvni modeli upravlinnia proektamy $v$ prohramno-tsilovomu upravlinni [Cognitive models of project management in targeted-oriented management]. Mistobuduvannia ta terytorialne planuvannia: nauk.-tekhn. zb. [Urban planning and spatial planning: Scientific and Technical Collection], 2010, no. 38, pp. 84-89.

7. Koshkin K. V., Makeyev S. A., Fomenko G. B. Kognitivnyye modeli upravleniya zhilishchno-kommunalnym khozyaystvom kak aktivnoy sistemoy [Cognitive models of housing and communal services management as an active system]. Upravlinnia rozvytkom skladnykh system [Management of com- plex systems development], 2011, no. 5, pp. 17-19.

8. Danchenko E. B. Kognitivnoye modelirovaniye riskov proyekta [Cognitive modeling of project risks]. Tezy dopovidey X mizhnarodnoi konferentsii "Upravlinnia proektamy $u$ rozvytku suspilstva. Tema: Upravlinnia prohramamy ta proektamy $v$ umovakh hlobalnoi finansovoi kryzy [Proceedings of the $10^{\text {th }}$ International Conference "Project Management in the Development of Society". Subject: Management of programs and projects under the global financial crisis]. Kyiv, 2013, pp. 64-66.

9. Didkovskyi S. V. Orhanizatsia refleksyvno-kohnityvnoho spilkuvannia $v$ protsesakh vyrishennia konfliktiv [Organization of reflective-cognitive communication in conflict solution process]. Aktualni problemy psykholohii: psykholohichna teoriia i tekhnolohiia navchannia [Current problems of psychology: psychological theory and learning technology], 2010 vol. 8, issue 7, pp. 52-62.

10. Danchenko O. B, Bedrii D. I., Semko I. B. Identyfikatsiia kadrovykh ryzykiv naukovykh proektiv [Identification of personnel risks of scientific projects]. Upravlinnia proektamy ta rozvytok vyrobnytstva: $z$ b. nauk. pr. [Project management and development of production: Collection of Scientific Publications], 2017, no. 4 (64), pp. 18-24.

11. Danchenko O. B, Bedriy D. I., Semko I. B. Upravlinnia konfliktamy naukovoho proektu [Management of conflicts of scientific project]. Visnyk NTU "KhPI" [Bulletin of the National Technical University "KhPI"], 2019, no. 2 (1327), pp. 28-35. DOI: 10.20998/2413-3000.2019.1327.5.

12. Bedrii D.I. Identyfikatsiia konfliktiv u naukovykh proektakh [Identification of conflicts in scientific projects]. Materialy III Mizhnarodnoi naukovo praktychnoi konferentsii "Project, Program, Portfolio Management" [Proceedings $3^{\text {rd }}$ of the International Scientific and Practical Conference "Project, Program, Portfolio Management”]. Odesa, 2018, pp. 17-20. 